\title{
Prawa osób wykluczonych w nauczaniu Jana Pawea II
}

\section{Wykluczeni i wykluczenie we współczesnej kulturze}

We współczesnej kulturze zglobalizowanych społeczeństw wykluczenie posiada swoje własne cechy charakterystyczne, pozostające w zależności od struktur społecznych, konstruowanych na podstawie modeli i stylów życia, które często nie uwzględniają należycie postulatu solidarności i zorientowane są na cele powierzchowne i nadmiernie angażujące (jak na przykład troska o dobrobyt ekonomiczny, zysk, posiadanie czy wygląd). Oznacza to, że w relacjach między ludźmi (a także między ludźmi i strukturami władzy) dominuje dążenie do osiągnięcia własnej korzyści. W związku z obowiązywaniem tej logiki, nierzadko odnotowuje się zjawiska egoizmu i wykluczenia. Jeśli bowiem ktoś okazuje się nieprzystający do dominującej struktury relacyjnej i społecznej, zostaje umieszczony na marginesie i wykluczony z relacji społecznych. To z kolei oznacza stopniowe odmawianie mu praw i godności. Zjawiska te i zachowania decydują o wewnętrznie sprzecznym charakterze naszych społeczeństw, w ramach których jednocześnie obecne są postawy odwołujące się do cnót i negujące je, polityka integracji i marginalizacji, działania włączające i wykluczające.

Logika wykluczenia i marginalizacji jest też wyrazem mentalności konsumistycznej i społeczeństwa zdominowanego przez rynek. Zgodnie z tą mentalnością osobiste szczęście i dobrobyt można w jakiś sposób „nabyć” i „zakontraktować”, oferując jedno dobro w celu uzyskania innego.

\footnotetext{
* Prof. dr, Università degli Studi di Bari Aldo Moro.
} 
Z tego wynika, że ci, którzy nie mają żadnej konkretnej korzyści do „zaoferowania”, oraz ci, którzy okazują się „odmienni” od zwykłego standardu społecznego, są sytuowani poza wspólnotą. Mentalność konsumistyczna odnosi się nie tyle do dóbr posiadających wartość ekonomiczna, ale przede wszystkim do dóbr, których posiadanie i używanie określa status społeczny, generując system sygnałów wpływających na wzorce zachowań oraz ideologię konsumistycznego społeczeństwa ${ }^{1}$.

Pojęcie konsumpcji odnosi się również do wartości zewnętrznych, związanych z przyznaniem określonego statusu społecznego, wyrażającego społeczny dobrobyt i mającego swe uzasadnienie w posiadaniu i używaniu dóbr (albo też określonego rodzaju dóbr) ${ }^{2}$. Poszczególne dobra są pożądane i nabywane właśnie dlatego, że pozwalają na wyróżnienie się i uzyskanie szczególnego statusu społecznego. Skoro jednak ich zasoby (a więc również i „podaż”) są ograniczone, logika ta przyczynia sie pośrednio do utrwalania podziałów istniejących pomiędzy tymi, „którzy posiadają” i tymi, „którzy nie posiadają". Ustalenie przebiegu granicy pomiędzy "posiadaniem” i jego brakiem pozwala na zidentyfikowanie tzw. „marginesu społecznego".

Chodzi o problem, który może być rozważany w dwóch aspektach. Pierwszy z nich, o charakterze przedmiotowym, dotyczy właśnie określenia "marginesu”, a więc ustalenia linii podziału. Natomiast drugi, podmiotowy, odnosi się do zidentyfikowania tych, którzy są "na granicy” albo „na zewnątrz”. Od odpowiedzi na wiążace się z tym pytania zależy „lista” tych, którzy są faktycznie wykluczeni. Zwrócić trzeba przy tym uwagę, że ta „lista” staje się coraz dłuższa, gdyż dokonujące się w na-

${ }^{1}$ Bardzo liczne są studia (mające już dziś charakter klasycznych) na temat relacji istniejącej pomiędzy dobrami, konsumpcją i państwem opiekuńczym, poczynając od badań T.B. Veblena. Na temat ekspansywnego charakteru „logiki produktów”, ujmowanej jako logika kontroli procesów decydujących o znaczeniu, zob. m.in. J. Baudrillard, Il sistema degli oggetti, Milano 2003.

2 W nieodległej przeszłości wyższy poziom świadomości dotyczącej konieczności poszanowania wartości ludzkich o charakterze absolutnym zaowocował w środowisku społecznym i politycznym licznymi teoriami krytycznymi wobec idei społeczeństwa konsumcyjnego ze względu na degeneracyjny potencjał wyrażający się zwłaszcza w rozszerzaniu się zachowań indywidualnych bezkrytycznie dostosowywanych do modeli rynkowych. Na uwagę zasługują w szczególności prace, których autorami są: H. Marcuse, M. Horkheimer, T.W. Adorno, J. Habermas. Natomiast w środowisku katolickim należy zwrócić uwagę na krytykę formułowaną - w ślad za encyklikami społecznymi - przez takich autorów, jak: F. Alberoni, G. Costa, L. Bruni, S. Zamagni. Zob. też prace, których autorami są H. Jonas i H. Harend. 
szych społeczeństwach szybkie zmiany rzadko spotykają się z adekwatnymi reakcjami. Odnosząc się do współczesnej sytuacji można stwierdzić, że na tej „liście” znajdują się bezdomni, emigranci z pańtw słabo rozwiniętych, osoby dotknięte różnymi deficytami (czy to fizycznymi czy umysłowymi), terminalnie chorzy, osoby narażone na uprzedzenia społeczne, kobiety znajdujące się w sytuacjach związanych z osłabieniem ich pozycji czy dzieci pozbawione ochrony. Wynika stąd przede wszystkim, że zgodnie z logiką współistnienia sprzeczności społecznych, nasze społeczeństwa traktują marginalizację jako zjawisko "akceptowalne” i „akceptowane" czy też - innymi słowy - jako niedłączny element społecznej koegzystencji.

Trzeba jednak również zwrócić uwagę, że obraz współczesnej rzeczywistości nie jest całkowicie negatywny, gdyż, przynajmniej z punktu widzenia wartości fundamentalnych dla każdej osoby ludzkiej, podejmuje się wiele działań mających na celu ograniczenie zjawisk marginalizacji i wykluczenia. Mamy na myśli na przykład unijną inicjatywę ogłoszenia roku 2010 Europejskim Rokiem Walki z Ubóstwem i Wykluczeniem Społecznym. Istotne znaczenie posiada również, przyjęta we wrześniu 2000 r., Deklaracja Milenijna Narodów Zjednoczonych określająca milenijne cele rozwoju (Millennium Development Goals), w której podjęto również kwestię walki z ubóstwem ${ }^{3}$. U podstaw wszystkich tych działań leży przekonanie, że rozwiązanie problemu wykluczenia społecznego, szeroko obecnego również w najbogatszych i najbardziej rozwiniętych społeczeństwach, sprzyja dobrobytowi nie tylko poszczególnych obywateli, ale i globalnej wspólnoty.

Musimy też pamiętać, że niekiedy dochodzi do samowykluczenia z kontekstu społecznego na podstawie dobrowolnych decyzji (drop out). Decydujące się na to jednostki odrzucają możliwość akceptacji społeczeństwa dominującego, postępując w zgodzie z osobistymi zasadami, z których nie chcą rezygnować. Zjawisko to zasługiwałoby na większą uwagę.

${ }^{3}$ Resolution adopted by the General Assembly 55/2. United Nations Millennium Declaration, (A/RES/55/2), przekład na język polski: Deklaracja Milenijna Narodów Zjednoczonych. Rezolucja przyjęta na 55 sesji Zgromadzenia Ogólnego Narodów Zjednoczonych, Nowy Jork, 8 września 2000 r., www.unic.un.org.pl/dokumenty/deklaracja_milenijna.doc [dostęp: 20.11.2017 r.]. Wśród różnych projektów związanych z programem milenijnym ONZ warto zwrócić uwage na propozycje dotyczaca usług energetycznych na rzecz ubogich w różnych częściach świata, zob. V. Modi, S. McDade, D. Lallement, J. Saghir, Energy services for the Millennium Development Goals, Washington 2005, http://lutw.org/wp-content/uploads/Energy-services-for-the-millennium-development-goals.pdf [dostęp: 20.11.2017 r.]. 
Można więc stwierdzić, że wykluczenie jest rezultatem kulturowej konstrukcji współczesnych społeczeństw. Podstawowy problem ma zatem charakter społeczny i wiąże się z obowiązującymi w nich strukturami, ustawami, zasadami prawnymi, wartościami moralnymi i etyką publiczną. To one bowiem generują zjawisko marginalizacji. Analizując funkcjonowanie społeczeństw $\mathrm{z}$ uwzględnieniem ich wewnętrznej dynamiki należy więc zadawać pytania o to, kto decyduje o wzorcach społecznych i regułach, w konsekwencji których coraz więcej osób jest rozmyślnie spychanych na margines życia społecznego, a także o to, jakie są przyczyny tego stanu rzeczy.

\section{Koncepcja Jana Pawła II}

Na tle przedstawionych wyżej schematów, dominujących we współczesnej kulturze, łatwo dostrzec oryginalność spojrzenia obecnego w nauczaniu Jana Pawła II. Różnice pomiędzy tymi dwoma wizjami są bardzo głębokie, ponieważ całkowicie odmienne są założenia, stojące $u$ ich podstaw. Odmienne są zresztą również przyjmowane cele, a także działania planowane $\mathrm{w}$ celu przeciwstawienia się zjawiskom wykluczenia i marginalizacji oraz motywacja tych działań. Nawet w przypadku formalnych zbieżności (jak na przykład w razie planowania wspólnych działań nakierowanych na ochronę osoby ludzkiej i jej fundamentalnych praw), głębokie pozostają różnice wynikające z odmienności przyjmowanych perspektyw.

Podkreślanie obowiązku troski o osoby marginalizowane stanowiło stały element nauczania Jana Pawła II i było wyrazem jego zatroskania o człowieka postrzeganego jako obraz Boży i droga Kościoła. Zwracanie uwagi na osoby marginalizowane nie miało przy tym charakteru instrumentalnego i nie służyło osiąganiu innych, ukrytych celów. Było motywowane świadomością niezbywalnej godności i wartości każdego człowieka i odnosiło się do różnych wymiarów ludzkiej egzystencji. Czytelną prezentację myśli papieża - Polaka możemy odnaleźć $\mathrm{w}$ jego licznych wypowiedziach, a zwłaszcza w trzech encyklikach społecznych (Laborem exercens z $1981 \mathrm{r} .^{4}$, Sollicitudo rei socialis z $1987 \mathrm{r}{ }^{5}$

\footnotetext{
${ }^{4}$ AAS 73(1981) 577-647.

${ }^{5}$ AAS 80(1988) 513-586.
} 
i Centesimus annus z $1991 \mathrm{r}^{6}{ }^{6}$ ) oraz encyklikach podejmujących kwestie antropologiczne (Veritatis splendor z 1993 r. ${ }^{7}$, Evangelium vitae z 1995 r. ${ }^{8}$ oraz Fides et ratio z 1998 r. $\left.{ }^{9}\right)$. Szczególną uwagę należy przy tym zwrócić na pierwszą encyklikę Jana Pawła II (Redemptor hominis z 1979 r. ${ }^{10}$ ), którą można uważać za punkt wyjścia dla wszystkich pozostałych oraz za wykład podstawowych elementów jego koncepcji11. Z kolei na przykład Orędzie na Wielki Post 1998 roku może być uznane za w pewien sposób podsumowujące jego myśl. "Zepchnięcie najsłabszych na margines społeczeństwa i pozbawienie bezrobotnych udziału w systemie produkcji” zostało tu przedstawione jako forma ubóstwa, to jest jako sytuacja osób pozostających $\mathrm{w}$ potrzebie wynikającej z ograniczeń w ich dostępie do dóbr i usług. Walkę z ubóstwem Jan Paweł II postrzegał w tym kontekście jako czyn Kościoła, który jest „Matką i troszczy się o to, aby każdy człowiek mógł żyć w sposób w pełni odpowiadający godności dziecka Bożego [...]. Przyjęcie przez Chrystusa ludzkiej kondycji we wszystkich jej aspektach, w tym także ubóstwa, cierpienia i śmierci, sprawia, że może się w Nim odnaleźć każdy człowiek"12.

W centrum problemu wykluczenia znajduje się człowiek, który nie może być traktowany jako coś abstrakcyjnego i teoretycznego. Chodzi o człowieka rozpatrywanego „w całej prawdzie swego istnienia i bycia osobowego, a zarazem «wspólnotowego», oraz jednocześnie «społecznego»", który dlatego ,jest pierwszą droga, po której winien kroczyć Kościół w wypełnianiu swojego posłannictwa, jest pierwsza i podstawowa droga Kościoła" (Redemptor hominis, 14).

${ }^{6}$ AAS 83(1991) 793-867.

7 AAS 85(1993) 1133-1228.

8 AAS 87(1995) 401-522.

9 AAS 91(1999) 5-88.

10 AAS 71(1979) 257-324.

${ }_{11}$ Opracowania dotyczące myśli papieża Jana Pawła II na temat kultury, wartości osoby ludzkiej, nauki oraz tematów pokrewnych są bardzo liczne, zob. w szczególności: R. Buttiglione, Il pensiero dell'uomo che divenne Giovanni Paolo II, Milano 1998; L. Negri, L'uomo e la cultura nel magistero di Giovanni Paolo II, Milano 2003; A. Strumia, L'uomo e la scienza nel magistero di Giovanni Paolo II, Casale Monferrato 1987; S. Grygiel, L'antropologia di Giovanni Paolo II, http://www.collevalenza.it/CeSAM/08_CeSAM_0088.htm [dostęp: 20.11.2017 r.]; A. Malo, L'antropologia di K. Wojtyla come sintesi del pensiero classico e della modernità, „Acta Philosophica” 2006, t. 15, z. 1, s. 11-28; O. Fumagalli Carulli, Il governo universale della Chiesa e i diritti della persona, Milano 2007.

${ }_{12}$ Messaggio di Giovanni Paolo II per la Quaresima 1998, https://w2.vatican.va/content/johnpaul-ii/it/messages/lent/documents/hf_jp-ii_mes_09091997_lent-1998.html [dostęp: 20.11.2017 r.]. 
Każdy człowiek przeżywa doświadczenie życia między dobrem a złem, między postępem a regresem, między przynależnością a wykluczeniem. Przeżywa „,wielki dramat, wobec którego nikt nie może pozostać obojętny. Podmiotem, który z jednej strony stara się wydobyć maksimum korzyści - z drugiej strony zaś tym, który płaci haracz krzywd, poniżeń jest zawsze człowiek" (Redemptor hominis, 16).

Marginalizacja może być określona jako produkt uboczny kultury konsumistycznej, ponieważ nie poświęca się w niej uwagi tym, którzy nie są zainteresowani albo nie mają możliwości uczestniczenia w konsumistycznym pędzie, angażującym wszystkie sfery działania człowieka, poczynając od pracy i sposobu spędzania wolnego czasu, a kończąc na zainteresowaniach i zamiłowaniach ${ }^{13}$. W swej istocie konsumizm owocuje nie tylko wykluczeniem wielu członków społeczności, ale i prowadzi do relatywizacji podstawowych wartości życiowych, w tym wartości duchowych i religijnych.

Szczególne miejsce pośród symptomów opisujących wykluczenie zajmuje kwestia pracy ludzkiej, która ,stanowi klucz, i to chyba najistotniejszy klucz do całej kwestii społecznej, jeżeli staramy się ją widzieć naprawdę pod kątem dobra człowieka" (Laborem exercens, 3). Praca ludzka nabiera fundamentalnego i decydującego znaczenia zwłaszcza dlatego, że jej ludzki wymiar ściśle wiąże się z jej wymiarem teologicznym: praca jest „rozumiana jako działalność "przechodnia»”, gdyż odnosi się do określonego przedmiotu (ziemia) i Bożego mandatu („,czyńcie ją sobie poddaną"). Jest rzeczą oczywista, że brak pracy powoduje poważny stan wykluczenia społecznego i egzystencjalnego, ponieważ uderza zarówno w samą godność człowieka, jak i w całą złożoność procesów produkcyjnych. Praca nie oznacza bowiem nigdy jedynie zajmowania jakiegoś stanowiska pracy, ale stanowi fundamentalny obowiązek moralny, którego realizacja pozwala na zrozumienie naszego miejsca i zadania w świecie ${ }^{14}$.

Marginalizacja nie jest jedynie zjawiskiem dotykającym indywidualne osoby, ale jawi się ona dzisiaj również jako dramat o charakterze kolektywnym, spotęgowany przez „fakt, że w bliskim sąsiedztwie upośledzonych egzystują środowiska uprzywilejowane”. Natomiast "fakt istnienia krajów wysoko rozwiniętych, które w stopniu nadmiernym gromadzą dobra, których bogactwo staje się nieraz przez nadużycie przyczyną różnych

${ }_{13}$ Zob. M. Consoli, La crisi dell'uomo nella società dei consumi, http://www.uomolibero. com/archivio/2/2D.htm [dostęp: 20.11.2017 r.].

${ }^{14}$ L. Bruni, Economia con l'anima, Bologna 2013, s. 75. 
schorzeń - dramat ten jeszcze zaostrza. Niepokój inflacji i plaga bezrobocia - oto inne jeszcze objawy tego moralnego nieładu, jaki zaznacza się w sytuacji świata współczesnego, która przeto domaga się rozwiązań odważnych i twórczych, zgodnych z autentyczną godnością człowieka" (Redemptor hominis, 16). Różnorodne przejawy marginalizacji (indywidualnej i kolektywnej), w przekonaniu Jana Pawła II są konsekwencją moralnego nieładu, który rozszerza się w sposób coraz bardziej dynamiczny.

Inną jeszcze formą wykluczenia jest - zdaniem papieża Wojtyły zabijanie inicjatywy, czyli uśmiercanie zdolności osoby do przekładania idei w działanie poprzez objawiające się w życiu codziennym realizowanie własnych kompetencji ze świadomością kontekstu, w którym się działa oraz możliwości, które się posiada. Ta forma wykluczenia rodzi poczucie „frustracji lub beznadziejności” oraz stanowi podatny grunt dla „braku zaangażowania w życie narodowe" (Sollicitudo rei socialis, 15), skoro „wśród wielu praw człowieka ograniczane jest prawo do inicjatywy gospodarczej, które jest ważne nie tylko dla jednostki, ale także dla dobra wspólnego. Doświadczenie wykazuje, że negowanie tego prawa, jego ograniczanie w imię rzekomej «równości» wszystkich w społeczeństwie, faktycznie niweluje i wręcz niszczy przedsiębiorczość, czyli twórczą podmiotowość obywatela. $W$ rezultacie kształtuje się $\mathrm{w}$ ten sposób nie tyle równość, ile «równanie w dół». Zamiast twórczej inicjatywy rodzi się bierność, zależność i podporządkowanie wobec biurokratycznego aparatu, który jako jedyny «dysponent» $\mathrm{i}$ «decydent», jeśli nie wręcz «posiadacz» ogółu dóbr wytwórczych stawia wszystkich w pozycji mniej lub bardziej totalnej zależności, jakże podobnej do tradycyjnej zależności pracownika proletariusza w kapitalizmie" (Sollicitudo rei socialis, 15).

Aspektem omawianego zjawiska, szczególnie mocno podkreślanym przez Jana Pawła II, jest wreszcie również wykluczenie narodów. „Ujmując rzecz z punktu widzenia gospodarczego liczba krajów na drodze rozwoju znacznie, niestety, przewyższa liczbę krajów rozwiniętych, a rzesze ludzi pozbawionych dóbr i usług, jakie niesie ze sobą rozwój, są nieporównanie liczniejsze od tych, które z tych dobrodziejstw korzystają. Stoimy zatem wobec poważnego problemu nierównomiernego podziału środków potrzebnych do życia, przeznaczonych z natury dla wszystkich ludzi, a więc również dobrodziejstw z nich wynikających. Dzieje się tak nie $\mathrm{z}$ winy rzesz upośledzonych ani tym mniej na skutek nieuchronnych konieczności wynikających $\mathrm{z}$ warunków naturalnych czy też w wyniku zbiegu okoliczności w ogóle" (Sollicitudo rei socialis, 9). Wykluczenie 
z udziału w globalnych procesach handlowych i finansowych oraz nowe formy ekonomicznego kolonializmu są dziś przyczyną sporych deficytów dostrzegalnych w budżetach krajów Trzeciego Świata w związku z realizacją płatności w handlu międzynarodowym. Jest prawdą że międzynarodowy porządek ekonomiczny, powstały w konsekwencji procesów globalizacyjnych, ułatwił przepływ kapitałów i liberalizację rynków. Jest też jednak prawda, że przyczynił się również do dalszej marginalizacji Trzeciego Świata. Przemawiająca jest w tym zakresie sytuacja państw afrykańskich, których marginalizacja stale przyspiesza, a globalizacja rynku przyczynia się do uwypuklenia ich słabości. Trzeba przy tym podkreślić, że Jan Paweł II przewidział ten efekt. W związku z tym inicjował coraz to nowe wysiłki i działania pastoralne, skierowane do krajów afrykańskich. Był bowiem świadom niesprawiedliwości, jaką dotknięte są niejednokrotnie całe narody, wykluczone z globalnego życia ekonomicznego.

W zgodzie z tą diagnoza, w encyklice Centesimus annus z $1991 \mathrm{r}$. Jan Paweł II podniósł kwestię „równego dostępu do międzynarodowego rynku" z wykorzystaniem posiadanych zasobów ludzkich. Kierował się świadomością, że ten, kto nie dotrzymuje kroku, jest marginalizowany. Degeneracyjne mechanizmy procesu marginalizacji mają różną naturę (ideologiczna, ekonomiczną, społeczną, ekologiczną, polityczna, kulturalną itd.), stale uderzają jednak w najsłabszych. Dominująca ideologia dobrobytu, efektywności, konsumizmu i produktywności prowadzi do wykluczenia tych, którzy są postrzegani jako nieefektywni czy nisko produktywni. Natomiast niewydolność systemów ekonomicznych generuje kolejne kryzysy, odbierając inicjatywę jednostkom i całym grupom, przedmiotowo postrzeganym jako element systemu, a nie jako protagoniści ${ }^{15}$.

Wśród ekonomicznych i społecznych wskaźników niedorozwoju należy dostrzec także inne, tak samo negatywne i niepokojące. Widać je na płaszczyźnie kulturalnej, poczynając od analfabetyzmu, poprzez trudność czy wręcz brak dostępu do wyższych poziomów wykształcenia, aż po niezdolność uczestniczenia w procesie kształtowania przyszłości własnego narodu. Przybierają one również postać różnorodnego wykorzystania osoby ludzkiej, jej ucisku ekonomicznego, społecznego, politycznego, a nawet religijnego. Owocują ograniczaniem przysługujących jej praw

15 Zob. A. Capasso, Centesimus annus. Il messaggio di un enciclica. 23.04.2007, http:// www.instoria.it/home/centesimus_annus.htm [dostęp: 20.11.2017 r.]. Na temat wartości osoby jako aktora i beneficjenta procesów ekonomicznych, zob. np. T. Chiminazzo, Etica ed economia. Il mercato e l'economia di solidarietà nell'era della globalizzazione, Milano 2007. 
i różnymi postaciami dyskryminacji, zwłaszcza tą najbardziej obrzydliwa, która oparta jest na odmienności etniczno-rasowej.

Zgodnie z oceną papieża - Polaka zjawisko wykluczenia ma wielkie rozmiary i dotyka wielu aspektów życia człowieka, który jest jednocześnie jego ofiarą i sprawcą. Wykluczenie jest zjawiskiem złożonym, które wyraża stan ubóstwa zauważalnego na różnych płaszczyznach (osobistej, kolektywnej, narodowej). W konsekwencji człowiek wykluczony jest „nosicielem stanu potrzeby”, będąc również świadkiem historycznego konfliktu między dwiema stronami zaangażowanymi w spór, który zapowiada przyszły moment finalny. Stronami gry, zgodnie z terminologią ewangeliczną, są Bóg i mamona, reprezentując kategoryczną alternatywę, bez jakiejkolwiek możliwości sprzymierzenia się, mediacji, negocjacji czy rozejmu. Przyczyną i przedmiotem tej walki jest sam człowiek, jego godność i jego zbawienie. Jest on też jednak protagonistą, posiadając zdolność opowiedzenia się za jedną ze stron ${ }^{16}$.

\section{Kwestia antropologiczna}

Zjawisko wykluczenia odnosi się do kwestii antropologicznej podejmowanej w encyklikach społecznych Jana Pawła II (trzech spośród czternastu). Chodzi o kwestię mającą naturę naukową i racjonalna, ale zarazem kwestię, która dotyka samej istoty misji Kościoła. W istocie chodzi bowiem o odpowiedź na stale aktualne pytanie św. Piotra, odnoszące się do odwiecznego dylematu człowieka: „Panie, do kogóż pójdziemy? Ty masz słowa życia wiecznego" (J 6, 68). Wykluczenie jest problemem, z którym wiąże się zasadnicze pytanie (o charakterze społecznym, politycznym, filozoficznym, moralnym, religijnym), na które należy udzielić odpowiedzi antropologicznej i chrystologicznej, trafiającej do serca człowieka, że bez Chrystusa nie ma nadziei. Chrystus jest nie tylko wzorem życia, który może zostać przez człowieka przyjęty lub odrzucony. Jest też odpowiedzia, gdyż przyjął ludzką naturę we Wcieleniu i odnowił ją przez

16 Coraz bardziej dramatyczne odseparowanie ekonomii od etyki stanowi bez wattpienia jedną z bardziej palących kwestii społecznych. Konieczne jest przywrócenie znaczenia wartości ogólnoludzkich, ze świadomością odpowiedzialności poszczególnych ludzi jako potencjalnych autorów potrzebnych zmian. Zob. L. Bechetti, G. Florio, Dio e Mammona. Dialogo tra un economista e un biblista su economia, etica e mercato, Roma 2014. 
śmierć i Zmartwychwstanie. Jezus ,jest gwarantem niezniszczalnej godności każdego człowieka, a zarazem jest Tym, który pokonuje indywidualizm w komunikowaniu, do którego dąży cała natura człowieka"17.

Kwestia antropologiczna ${ }^{18}$ sytuuje się w centrum każdej kultury i stanowi fundament zarówno wspólnej koegzystencji, jak i prawa pozytywnego. Odniesienie sie do niej pozwala najlepiej opisać kryzys współczesnych czasów, który, zgodnie z oceną Jana Pawła II, jest przede wszystkim „kryzysem antropologicznym”. Problem antropologiczny został zresztą z przekonaniem podjęty zarówno przez papieża Benedykta XVI, jak i przez papieża Franciszka. W swoich encyklikach przedstawili oni w tej kwestii nowe analizy i nowe propozycje, nawiązując jednak do ujęcia chrystocentrycznego, charakterystycznego dla nauczania Jana Pawła II. Podkreślanie tego transcendentalnego aspektu pozwala na maksymalne rozszerzenie spojrzenia, ponieważ stanowi on "punkt wyjścia”, którego przyjęcie jest konieczne, ale nie zamyka dyskusji. „Pomiędzy punktem wyjścia i punktem docelowym jest czas na wędówkę, a w tej wędrówce Kościół towarzyszy człowiekowi" ${ }^{19}$.

Złożoność kwestii antropologicznej najłatwiej dostrzec wówczas, gdy się ją analizuje z perspektywy takich właśnie zjawisk, jak ubóstwo czy wykluczenie. Stymulują one bowiem odpowiedzi uwzględniające relacje pomiędzy wiarą i nauką która oferuje środki potrzebne do stawienia czoła omawianym problemom. Odpowiedzialność naukowca wynika z jedności dzieła Bożego, ponieważ poszukuje on prawd dotyczących różnorodnych kwestii, które zbiegają się w jednej Prawdzie. Służąc Prawdzie, powinien

17 J. Ratzinger, Las catorce encíclicas del Santo Padre Juan Pablo II (Congreso „Juan Pablo II: 25 años de pontificado. La Iglesia al servicio del hombre", Pontificia Universidad Lateranense, Roma. 8-10 de mayo 2003), http://www.vatican.va/roman_curia/congregations/ cfaith/documents/rc_con_cfaith_doc_20030509_ratzinger-simposio_laterano_sp.html [dostęp: 20.11 .2017 r.].

${ }_{18}$ Problem antropologiczny posiada dziś znaczenie szczególne. Jak zauważa G. La Pira, jego aktualność wynika z tego, że „ekonomia, prawo, kultura, polityka, technika, bioetyka i biopolityka zależą od określonych koncepcji człowieka". We wszystklich tych zakresach zagadnienia antropologiczne zajmują miejsce centralne, zob. G. La Pira, Il valore della persona umana, Firenze 2009.

${ }_{19}$ R. Buttiglione, L'Approccio antropologico di San Giovanni Paolo II e quello pastorale di papa Francesco, http://www.lastampa.it/2017/02/03/vaticaninsider/ita/documenti [dostęp: 20.11.2017 r.]. Kwestie antropologiczne były ważne już dla Karola Wojtyły - filozofa, zob. m.in. K. Wojtyła, Osoba i czyn oraz inne studia antropologiczne, Lublin 1994, tłumaczenie na j. włoski: K. Wojtyła, Metafisica della persona ed altri saggi integrativi, G. Reale, T. Styczeń (red.), Milano 2003; zob. także R. Buttiglione, Il pensiero dell'uomo che divenne Giovanni Paolo II, Milano 1998. 
on pozostawać na służbie człowieka i jego najgłębszych potrzeb. Kościół ze swej strony, pozostając wierny swojej misji, powinien prowadzić dialog ze współczesnymi osiągnięciami nauki, aby pomócczłowiekowi w „,czynieniu sobie ziemi poddaną” (Rdz 1, 28) i przezwyciężeniu ubóstwa, które jest głębokim zaprzeczeniem Prawdy. Zobowiązanie to prowadzi do ciągłego poszukiwania społecznej dynamiki i pogłębiania humanizmu, który czyni człowieka odpowiedzialnym za swoją przyszłość, za wychowanie i dobro wspólne ludzkości (zob. przemówienie Jana Pawła II wygłoszone w siedzibie UNESCO w 1980 r. $)^{20}$. W tym ujęciu nauka powinna służyć człowiekowidorozwiązywaniajegoproblemów zeświadomością żeobecny kryzys społeczeństwa obywatelskiego wymaga przebudzenia wierzącej inteligencji. To przebudzenie musi opierać się na mocnych przekonaniach, które dotyczą kwestii fundamentalnych dla chrześcijańskiego sposobu postrzegania świata. Odnosząc się do nauczania Jana Pawła II (Veritatis splendor, Fides et ratio) można wśród nich wskazać na prawdę jako motor badań, jedność jako czynnik wyznaczający zakres badań, kulturę opartą na otwarciu i poszanowaniu pracy innych, szacunek wobec tego wszystkiego, co dał nam Stwórca, miejsce człowieka w przyrodzie, ludzką odpowiedzialność i troskę o przyszłość, a w końcu tajemnicę obecności Wieczności w czasie dzięki Zmartwychwstaniu Chrystusa. Uwaga, którą Jan Paweł II poświęcał nauce, związana była z pragnieniem stworzenia „kultury naukowej”, stanowiącej owoc spotkania wiary i rozumu w dążeniu do realizacji dobra człowieka i budowania dobra wspólnego zgodnie $\mathrm{z}$ koncepcją antropocentryczna, ponieważ to $\mathrm{w}$ człowieku znajduje się klucz do zrozumienia całego wszechświata ${ }^{21}$. Chodzi przy tym o wizję człowieka odkupionego przez Chrystusa. W ten sposób Jan Paweł II swoje uznanie dla kultury naukowej włącza w perspektywę chrystologiczną - w tę perspektywę, która była obecna w jego nauczaniu od pierwszych lat pontyfikatu, a zwłaszcza od czasu ogłoszenia encykliki Redemptor hominis (1979).

${ }^{20}$ Zob. Discorso di Giovanni Paolo II all'Organizzazione delle Nazioni Unite per l'educazione, la scienza e la cultura (UNESCO), http://w2.vatican.va/content/john-paul-ii/it/speeches/1980/ june/documents/hf_jp-ii_spe_19800602_unesco.pdf [dostęp: 20.11.2017 r.].

${ }^{21} \mathrm{Na}$ temat relacji człowieka i kultury w nauczaniu Jana Pawła II, zob. w szczególności: L. Negri, L'uomo e la cultura nel magistero di Giovanni Paolo II, Milano 2003. Odnosząc się zwłaszcza do przemówienia Jana Pawła II w UNESCO z 1980 r. autor podkreśla konsekwencję, z jaką papież uznaje człowieka nie tylko za podmiot, ale i za cel każdej kultury. 


\section{Misja Kościoła w kontekstach wykluczenia}

Główne myśli pontyfikatu Jana Pawła II, wśród których priorytetowe miejsce zajmuje obrona najsłabszych (ale też inne tematy społeczne o podobnym znaczeniu, jak dialog międzyreligijny, dialog w ramach społeczeństwa obywatelskiego, rola komunikacji międzyludzkiej itd.), znacząco wpłynęły na kościelną refleksję nad bardziej adekwatnymi sposobami głoszenia Ewangelii, które jest misją własną Kościoła ${ }^{22}$. Papież Wojtyła proponuje wiele sposobów odkrywania wierności Bogu i człowiekowi. Na przykład w encyklice Dives in misericordia z $1980 \mathrm{r} .{ }^{23}$ wskazuje na potrzebę naśladowania miłosierdzia Bożego, aby „pokonać niesprawiedliwość, nienawiść i okrucieństwo”, a Kościół określa jako „depozytariusza i szafarza Bożego miłosierdzia”. Chcąc pozostać wiernym misji głoszenia Ewangelii wszystkim narodom, Kościół powinien zatem pozostać „Kościołem ubogich".

Troska, jaką Jan Paweł II okazywał wobec wspólnot kościelnych w różnych regionach świata (Azja, Afryka, Ameryka, Europa), przebija również z posynodalnych adhortacji apostolskich im poświęconych w latach 1999-2003. Papież podkreślał różne specyficzne aspekty, które po ich połączeniu - składają się na obraz całościowy, uwidaczniający jedność misji kościelnej, w której każdy z Kościołów partykularnych uczestniczy na swój własny sposób. Na przykład pisząc do Kościołów Ameryki Jan Paweł II podkreślał potrzebę solidarności z różnymi kategoriami ubogich i wykluczonych. Zwracając się do Kościołów Oceanii akcentował apostolat społeczny (którego celem jest przekazywanie nadziei przez wkład do ludzkiego rozwoju, promocji praw człowieka, obrony życia i godności ludzkiej, sprawiedliwości społecznej i ochrony środowiska) oraz jedność $\mathrm{z}$ tymi, którzy występują przeciwko niesprawiedliwości, korupcji, zagrożeniu życia i nowym formom ubóstwa. Natomiast w przesłaniu do Kościołów Europy Jan Paweł II podkreślał obowiązek przyjmowania ubogich jak samego Chrystusa (zob. Mt 25, 40) i odnoszącą się do nich „miłość preferencyjną” jako konieczny wymiar bycia chrześcijaninem i służenia Ewangelii (ponieważ wszyscy ludzie posiadają własną wartość, niezależnie od warunków

${ }^{22} \mathrm{Na}$ temat ewolucji dostrzegalnej w nauczaniu papieskim, zob. F. Margiotta Broglio, Il papato degli ultimi cinquant'anni. Dalla "nuova cristianità" di Pio XII alla geopolitica di Karol Wojtyla, „Rivista di Studi Politici Internazionali” 1989, t. 56, nr 1, s. 47-56.

${ }^{23}$ AAS 72(1980) 1177-1232. 
ekonomicznych, kulturalnych i społecznych, w których żyją). Pośród wszystkich wykluczonych i marginalizowanych szczególną uwagą papież obdarzał dzieci, najsłabsze wśród najsłabszych, prawdziwy dar Boga, których Kościół - Matka nigdy nie może opuścić. Myśl ta była obecna zwłaszcza w przesłaniach kierowanych do Kościołów w Afryce.

Zasadność i potrzeba interwencji ze strony Kościoła (Sollicitudo rei socialis, 8) nie wynika przede wszystkim z etycznego i kulturalnego charakteru problemów dotyczących wykluczenia i rozwoju, ale - jak to zostało podkreślone $\mathrm{w}$ przemówieniu wygłoszonym przez papieża do duchowieństwa w Bogocie w 1986 r. - z „,czytelnej świadomości faktu, że pierwszym wyzwoleniem, o jakie człowiek powinien się starać, jest wyzwolenie od grzechu i zła moralnego, które zagnieżdża się w sercu"24. Wszędzie tam, gdzie dostrzegalne jest zjawisko wykluczenia, Kościół nie może milczeć ani być bierny, lecz powinien kierować się Ewangelią w dążeniu do sprawiedliwości i w trosce o obronę słusznych praw.

Misją Kościoła jest głoszenie Chrystusa i Jego Ewangelii wszystkim narodom. Ten zasadniczo misyjny wymiar nie oznacza jedynie, że Kościół „ma do spełnienia powszechną misję wobec całej ludzkości, lecz że w jego strukturze, w jego duszy, a więc niejako w jego «psychologii» zawiera się dynamizm, którego konkretnym przejawem jest przepowiadanie Ewangelii, szerzenie wiary i wzywanie do nawrócenia wszystkich «aż po krańce ziemi»”. Dlatego też „każdy wierny powinien w Kościele i wraz z Kościołem szerzyć światło Ewangelii zgodnie ze zbawczą misją powierzoną Wspólnocie kościelnej przez Odkupiciela"25.

We wskazaniach papieża - Polaka ewangelizacyjna misja Kościoła obejmuje energiczne i poważne działanie na rzecz sprawiedliwości, pokoju i integralnego rozwoju człowieka. Niewypełnianie tych zadań oznaczałoby niesprostanie wymogom Ewangelii i zdradzenie przykładu Jezusa, który przyszedł „aby ubogim nieść dobrą nowinę” (Łk 4, 18). W swej istocie byłoby więc odrzuceniem konsekwencji Wcielenia, które oznacza, że „Słowo stało się ciałem" (J 1, 14). Ta misja jest sprawowaniem macierzyństwa duchowego, które realizuje się (Kościół jest tego świadomy)

${ }^{24}$ Incontro di Giovanni Paolo II con i sacerdoti, i seminaristi e i religiosi, Bogotá 1986, http://w2.vatican.va/content/john-paul-ii/it/speeches/1986/july/documents/hf_jp-ii_ spe_19860701_sacerdoti-bogota.pdf [dostęp: 20.11.2017 r.].

${ }_{25}$ Giovanni Paolo II, Udienza generale. 19.04.1995, http://w2.vatican.va/content/john-paul-ii/it/audiences/1995/documents/hf_jp-ii_aud_19950419.html [dostęp: 20.11.2017 r.]; tłumaczenie na j. polski: Jan Paweł II, Dzieła zebrane, Kraków 2007, t. 7, s. 756. 
„pośród «bólu i męki rodzenia» (Ap 12, 2), to znaczy w nieustannym zmaganiu z mocami zła, które nadal przenikają świat i oddziałują na ludzkie serca, stawiając opór Chrystusowi" (Evangelium vitae, 103). Proponowany przez Jana Pawła II sposób prowadzenia tej walki został zilustrowany w jego ostatnim orędziu na 38. Światowy Dzień Pokoju (2005 r.), którego myślą przewodnią były słowa św. Pawła: „nie daj się zwyciężać złu, ale zło dobrem zwyciężaj” (Rz 12, 21). Chodzi więc o drogę miłości, dzięki której możliwe stanie się konstruowanie nowej wspólnoty, ponieważ zła nie można zwyciężać złem. W omawianym przesłaniu, mającym cechy swego rodzaju testamentu, Papież podkreślił, że w sytuacji rozpowszechnionej kolektywnej niepewności dotyczącej dobra i zła, to ostatnie nie jest po prostu anonimową siła, ale „ma zawsze czyjąś twarz i czyjeś imię: twarz i imię mężczyzn i kobiet, którzy je dobrowolnie wybierają". Dlatego też, jak napomina Jan Paweł II w tym samym przesłaniu, „żaden człowiek dobrej woli - mężczyzna czy kobieta - nie może uchylać się od obowiązku walki, by zło zwyciężać dobrem", to znaczy obowiązku bycia gotowym do tego, by używać „broni miłości”. W istocie bowiem, „kiedy dobro zwycięża zło, króluje miłość, a gdzie króluje miłość, króluje pokój” $^{26}$.

\section{Kształt przysługujących praw}

Jan Paweł II miał bardzo konkretną koncepcję praw człowieka, gdyż uważał, jak to wyraził podczas przemówienia w siedzibie ONZ w 1979 r., że „człowiek żyje równocześnie w świecie wartości materialnych i w świecie wartości duchowych. Dla konkretnie żyjącego człowieka jego potrzeby, korzystanie z wolności i stosunki z drugimi nie ograniczają się wyłącznie do jednego lub drugiego zakresu wartości, ale dotyczą obu tych zakresów równocześnie" 27 . Zgodnie z tą wizja, zwracanie uwagi na

${ }^{26}$ Nie daj się zwyciężyć złu, ale zło dobrem zwyciężaj. Orędzie Ojca Świętego Jana Pawła II na Światowy Dzień Pokoju 1 stycznia 2005 roku, http://w2.vatican.va/content/john-paul-ii/pl/ messages/peace/documents/hf_jp-ii_mes_20041216_xxxviii-world-day-for-peace.pdf [dostęp: 20.11 .2017 r.].

${ }^{27}$ Tekst w j. polskim: Na forum pokoju i sprawiedliwości. Przemówienie do Zgromadzenia Ogólnego ONZ. Nowy Jork. 2.10.1979, 14, [w:] Jan Paweł II, Dzieła zebrane, Kraków 2009, t. 12, s. 24-34. 
sytuację osób wykluczonych z konieczności łączy się z demaskowaniem naruszeń praw człowieka i obroną podstawowych wolności człowieka, co stanowiło tematy podejmowane przez papieża - Polaka już od jego pierwszej encykliki. Jednoczesne i konkretne uwzględnianie obu wskazanych wymiarów prowadziło Jana Pawła II do zwrócenia uwagi na niebezpieczną tendencję, coraz mocniejszą we współczesnym społeczeństwach, jaką jest relatywizm etyczny. Poddawał więc jednoznacznie negatywnej weryfikacji rozpowszechnione przekonanie, że relatywizm stanowi „warunek demokracji, jako że tylko on miałby gwarantować tolerancję, wzajemny szacunek między ludźmi i uznanie decyzji większości, podczas gdy normy moralne uważane za obiektywne i wiążące prowadziłyby rzekomo do autorytaryzmu i nietolerancji" (Evangelium vitae, 70). Wyraźnie i z wyprzedzeniem dostrzegał rozpowszechnianie się takiej kultury demokratycznej, według której „,porządek prawny społeczeństwa powinien ograniczać się do utrwalania i przyswajania sobie przekonań większości i w konsekwencji winien być zbudowany wyłącznie na tym, co większość obywateli stosuje i uznaje za moralne" (Evangelium vitae, 69). Zgodnie z tą logiką, takie zjawiska jak wykluczenie, wyzysk czy ubóstwo, moga zostać moralnie zaakceptowane przez większość, prowadząc do prawodawczej interwencji władzy publicznej, która będzie zmuszać obywateli do rezygnowania ze swoich przekonań, przyjmując za ,,jedyne kryterium moralne w wypełnianiu swoich funkcji to, co zostało określone w tychże ustawach. W ten sposób odpowiedzialność osoby zostaje powierzona prawu cywilnemu, co oznacza rezygnację z własnego sumienia przynajmniej w sferze działalności publicznej". Przyjęcie tej logiki znaczyłoby również, że system demokratyczny „winien być zbudowany wyłącznie na tym, co większość obywateli stosuje i uznaje za moralne" (Evangelium vitae, 69).

Opisana wizja demokracji, sprowadzanej jedynie do obowiązywania woli większości, w ostatecznym rozrachunku stanowi jednak zdradę tego systemu. Nie ma zresztą jednej koncepcji demokracji. W historii przyjmowała ona różne formy, wiążąc się z różnymi ideami politycznymi, charakteryzującymi się niejednolitymi odpowiedziami na pytania dotyczące sposobu wyważenia wartości, które się na nią składają (partycypacja społeczna, efektywność władzy ludu, forma podejmowania wiążących decyzji, zasada państwa prawa, ochrona podstawowych praw i wolności). Zauważalnym dziś tendencjom do narzucania wykrzywionych wizji demokracji, postrzeganej jako doświadczenie o charakterze anonimowym, 
będzie można się przeciwstawić jedynie wówczas, gdy na nowo skoncentrujemy się na człowieku, który - według wizji Jana Pawła II - żyje jednocześnie „w sferze wartości materialnych i duchowych”, stanowiąc „wymiar zasadniczy, zdolny poruszyć aż do samych podstaw systemy decydujące o strukturze całej ludzkości" ${ }^{28}$.

Wartość demokracji trwa lub upada wraz z wartościami, jakie ona ucieleśnia i promuje. Fundamentalne i niezbywalne są z pewnością: godność każdej osoby ludzkiej, poszanowanie jej nienaruszalnych i niezbywalnych praw, jak również przyjęcie „,dobra wspólnego", jako celu i kryterium regulujące życie polityczne. W okresie kryzysu dotykającego współczesnych społeczeństw, skuteczna ochrona praw człowieka stanowi więc właściwą drogę przeciwstawienia się takim zjawiskom, jak wykluczenie czy ubóstwo. W tej perspektywie Papież proponuje poszukiwanie nowego humanizmu poprzez kierowanie się kryteriami natury humanistycznej w ocenie systemów ekonomicznych $\mathrm{i}$ ich zdolności doeliminowania (albohamowania) różnych form wyzysku, cojestmożliwe jedynie przez właściwą dystrybucję koniecznych dóbr materialnych oraz uczestniczenie poszczególnych ludzi w życiu społecznym i w procesach produkcyjnych w sposób odpowiadający ich godności. Jak podkreślił Jan Paweł II w czasie wizyty we włoskim Parlamencie w listopadzie 2002 r., „naprawdę humanistyczny charakter określonego ciała społecznego przejawia się zwłaszcza w uwadze, jaka potrafi ono wyrazić wobec swoich najsłabszych członków" ${ }^{29}$. W doświadczeniu papieża - Polaka koncepcja ta znalazła potwierdzenie również $\mathrm{w}$ historycznej kompromitacji antropologii socjalistycznej, sprowadzającej człowieka do roli elementu systemu społecznego ${ }^{30}$.

${ }^{28}$ Tłumaczenie na j. polski: Jan Paweł II, W imię przyszłości kultury. Przemówienie w siedzibie UNESCO, Paryż. 2.06.1980, 3, [w:] Jan Paweł II, Dzieła zebrane, Kraków 2008, t. 10, s. 99-108.

${ }^{29}$ Giovanni Paolo II, Discorso di Sua Santità Giovanni Paolo II. Visita al Parlamento Italiano in Seduta Pubblica Comune, Palazzo Montecitorio. 14.11.2002, http://w2.vatican.va/content/ john-paul-ii/it/speeches/2002/november/documents/hf_jp-ii_spe_20021114_italian-parliament.pdf [dostęp: 20.11.2017 r.].

30 Zob. G. Barberini, La grande Europa di Giovanni Paolo II, „Stato, Chiese e Pluralismo Confessionale. Rivista telematica" 2014, nr 34, s. 1-13, http://www.statoechiese.it/contributi/la-grande-europa-di-giovanni-paolo-ii [dostęp: 20.11.2017 r.]; C. Cardia, Karol Wojtyla: vittoria e tramonto, Roma 1994. Z perspektywy socjologicznej, zob. także D. De Masi, Mappa mundi. Modelli di vita per una società senza orientamento, Milano 2013. 


\section{Podsumowanie}

Temat ochrony praw człowieka, pojmowanych przez pryzmat niezbywalnej godności osoby ludzkiej, niezmiennie pozostaje w centrum zainteresowania Kościoła. Nierozerwalność związku pomiędzy prawami człowieka i wrodzoną godnością osoby ludzkiej podkreślana jest w licznych dokumentach Katolickiej Nauki Społecznej. Jak na to zwrócił uwagę Jan Paweł II w liście skierowanym do Przewodniczącego Stowarzyszenia Konferencji Biskupów Afryki Centralnej w 2002 r., fakt ten uzasadnia zaangażowanie Kościoła - obok wszystkich innych ludzi dobrej woli - na rzecz zapoczątkowania „,nowej epoki pokoju, sprawiedliwości i solidarności" oraz poszanowania fundamentalnych praw zarówno poszczególnych osób, jak i tworzonych przez nie wspólnot, z nadzieją na ich integralny rozwój ${ }^{31}$.

tłum. Krystyna Kozak, Piotr Stanisz

Słowa kluczowe: Jan Paweł II, wykluczenie, marginalizacja, ubóstwo, prawa człowieka

\section{Bibliografia}

Barberini G., La grande Europa di Giovanni Paolo II, "Stato, Chiese e Pluralismo Confessionale. Rivista telematica" 2014, nr 34, s. 1-13, http://www. statoechiese.it/contributi/la-grande-europa-di-giovanni-paolo-ii [dostęp: 20.11.2017 r.].

Baudrillard J., Il sistema degli oggetti, Milano 2003.

Bechetti L., G. Florio, Dio e Mammona. Dialogo tra un economista e un biblista su economia, etica e mercato, Roma 2014.

Bruni L., Economia con l'anima, Bologna 2013.

Buttiglione R., Il pensiero dell'uomo che divenne Giovanni Paolo II, Milano 1998.

Buttiglione R., L'Approccio antropologico di San Giovanni Paolo II e quello pastorale di papa Francesco, http://www.lastampa.it/2017/02/03/vaticaninsider/ita/ documenti/_[dostęp: 20.11.2017 r.].

${ }^{31}$ Lettera del Santo Padre Giovanni Paolo II al Presidente dell'Associazione delle Conferenze Episcopali dell'Africa Centrale, https:/w2.vatican.va/content/john-paul-ii/it/letters/2002/documents/hf_jp-ii_let_20020513_conf-episc-africa.html [dostęp: 20.11.2017 r.]. 
Capasso A., Centesimus annus. Il messaggio di un enciclica. 23.04.2007, http:// www.instoria.it/home/centesimus_annus.htm [dostęp: 20.11.2017 r.].

Cardia C., Karol Wojtyla: vittoria e tramonto, Roma 1994.

Chiminazzo T., Etica ed economia. Il mercato e l'economia di solidarietà nell'era della globalizzazione, Milano 2007.

Consoli M., La crisi dell'uomo nella società dei consumi, http://www.uomolibero. com/archivio/2/2D.htm [dostęp: 20.11.2017 r.].

De Masi D., Mappa mundi. Modelli di vita per una società senza orientamento, Milano 2013.

Fumagalli Carulli O., Il governo universale della Chiesa e i diritti della persona, Milano 2003.

Giovanni Paolo II, Discorso di Giovanni Paolo II all'Organizzazione delle Nazioni Unite per l'educazione, la scienza e la cultura (UNESCO), http://w2.vatican.va/content/john-paul-ii/it/speeches/1980/june/documents/hf_jp-ii_ spe_19800602_unesco.pdf [dostęp: 20.11.2017 r.].

Giovanni Paolo II, Discorso di Sua Santità Giovanni Paolo II. Visita al Parlamento Italiano in Seduta Pubblica Comune, Palazzo Montecitorio. 14.11.2002, http:// w2.vatican.va/content/john-paul-ii/it/speeches/2002/november/documents/ hf_jp-ii_spe_20021114_italian-parliament.pdf [dostęp: 20.11.2017 r.].

Giovanni Paolo II, Incontro di Giovanni Paolo II con $i$ sacerdoti, $i$ seminaristi e $i$ religiosi, Bogotá 1986, http://w2.vatican.va/content/john-paul-ii/it/speeches/1986/july/documents/hf_jp-ii_spe_19860701_sacerdoti-bogota.pdf [dostęp: 20.11.2017 r.].

Giovanni Paolo II, Lettera del Santo Padre Giovanni Paolo II al Presidente dell'Associazione delle Conferenze Episcopali dell'Africa Centrale, https://w2.vatican. va/content/john-paul-ii/it/letters/2002/documents/hf_jp-ii_let_20020513_ conf-episc-africa.html [dostęp: 20.11.2017 r.].

Giovanni Paolo II, Messaggio di Giovanni Paolo II per la Quaresima 1998, https:// w2.vatican.va/content/john-paul-ii/it/messages/lent/documents/hf_jp-ii_ mes_09091997_lent-1998.html [dostęp: 20.11.2017 r.].

Giovanni Paolo II, Udienza generale. 19.04.1995, http://w2.vatican.va/content/ john-paul-ii/it/audiences/1995/documents/hf_jp-ii_aud_19950419.html [dostęp: 20.11.2017 r.].

Grygiel S., L'antropologia di Giovanni Paolo II, http://www.collevalenza.it/CeSAM/08_CeSAM_0088.htm [dostęp: 20.11.2017 r.].

Jan Paweł II, Na forum pokoju i sprawiedliwości. Przemówienie do Zgromadzenia Ogólnego ONZ. Nowy Jork. 2.10 1979, [w:] Jan Paweł II, Dzieła zebrane, Kraków 2009, t. 12, s. 24-34.

Jan Paweł II, Nie daj się zwyciężyć złu, ale zło dobrem zwyciężaj. Orędzie Ojca Świętego Jana Pawła II na Światowy Dzień Pokoju 1 stycznia 2005 roku, http:// w2.vatican.va/content/john-paul-ii/pl/messages/peace/documents/hf_jp-ii_mes_20041216_xxxviii-world-day-for-peace.pdf [dostęp: 20.11.2017 r.]. 
Jan Paweł II, W imie przyszłości kultury. Przemówienie w siedzibie UNESCO, Paryż. 2.06.1980, [w:] Jan Paweł II, Dzieła zebrane, Kraków 2008, t. 10, s. 99108.

La Pira G., Il valore della persona umana, Firenze 2009.

Malo A., L'antropologia di K. Wojtyla come sintesi del pensiero classico e della modernità, "Acta Philosophica” 2006, t. 15, z. 1, s. 11-28.

Margiotta Broglio F., Il papato degli ultimi cinquant'anni. Dalla "nuova cristianità" di Pio XII alla geopolitica di Karol Wojtyla, „Rivista di Studi Politici Internazionali" 1989 , t. 56, nr 1, s. 47-56.

Modi V., S. McDade, D. Lallement, J. Saghir, Energy services for the Millennium Development Goals, Washington 2005, http://lutw.org/wp-content/uploads/Energy-services-for-the-millennium-development-goals.pdf [dostęp: 20.11.2017 r.].

Negri L., L'uomo e la cultura nel magistero di Giovanni Paolo II, Milano 2003.

Ratzinger J., Las catorce encíclicas del Santo Padre Juan Pablo II (Congreso „Juan Pablo II: 25 años de pontificado. La Iglesia al servicio del hombre", Pontificia Universidad Lateranense, Roma. 8-10 de mayo 2003), http://www.vatican.va/roman_curia/congregations/cfaith/documents/rc_ con_cfaith_doc_20030509_ratzinger-simposio_laterano_sp.html [dostęp: 20.11.2017 r.].

Resolution adopted by the General Assembly 55/2. United Nations Millennium Declaration, (A/RES/55/2), przekład na j. polski: Deklaracja Milenijna Narodów Zjednoczonych. Rezolucja przyjęta na 55 sesji Zgromadzenia Ogólnego Narodów Zjednoczonych, Nowy Jork. 8 września 2000 r., www.unic.un.org. pl/dokumenty/deklaracja_milenijna.doc [dostęp: 20.11.2017 r.].

Strumia A., L'uomo e la scienza nel Magistero di Giovanni Paolo II, Casale Monferrato 1987.

Wojtyła K., Metafisica della persona ed altri saggi integrativi, G. Reale, T. Styczeń (red.), Milano 2003.

Wojtyła K., Osoba i czyn oraz inne studia antropologiczne, Lublin 1994.

\section{RIGHTS OF THE EXCLUDED PERSONS IN THE TEACHINGS OF JOHN PAUL II}

\section{S u m m a r y}

The goal of the article is to point out the most important content of the teachings that John Paul II dedicated to the excluded and marginalized persons. The starting point is the characterization of the phenomenon of exclusion in contemporary culture and pointing out its fundamental causes, seen in the prevalent models and styles of life, which often do not take into account the postulate of solidarity and are oriented towards superficial goals and are engaging in ways disproportional to their real importance. 
Such a background allows for the presentation of the originality and timeliness of the thought of the Polish Pope, who was consistent in underlining the Christian duty to care for persons bereft of rights and access to basic goods, also pointing out the fact that the phenomenon of marginalization in the contemporary world affects not only individuals but also whole societies, including nations.

Separately accented you will find goals, which - according to John Paul II - are set before the Church in connection with broadening of the phenomena of marginalization and exclusion. The most important consist of imitating God's mercy, attitude of solidarity, preferential love for the poor and engaging in the promotion and defense of the inalienable rights of each person.

Key words: John Paul II, marginalization, poverty, human rights

\section{ПРАВА ЛИЦ, ИСКЛЮЧЕННЫХ В УЧЕНИИ ИОАННА ПАВ АА І I}

$$
\text { P е } 3 \text { ю м е }
$$

Целью статьи является обращение внимания на важнейшие содержания учения, которое Иоанн Павел II посвятил исключенным и маргинализированным дицам. Исходной точкой является то, чтобы охарактеризовать явление исключения в современной культуре и указание его первичных причин, которые наблюдаются в распространенных моделях и стилях жизни, которые часто не учитывают постулата содидарности и сориентированы на поверхностные и ангажирующие цели в не пропорциональный способ к их реальному бремени. На таком фоне указана оригинальность и актуальность мысли Папы-Поляка, который последовательно подчеркивал христианскую обязанность заботы о лицах дишение прав и доступа к основному благу, также обращая внимание на факт, что явление маргинализации в современном мире касается не только единиц, но и целых сообществ, в том числе народов. Отдельно акцентированые остались задания, которые, - по мнению Иоанна Павла II - стоят перед Церковью в связи с расширением явлений маргинализации и искдючения. Важнейшие из них подлежат к подражанию Божьего милосердия, положении солидарности, преференциальной любви относительно бедных, а также ангажировании в акцию и защиту неотъемлемых прав каждого человека.

Ключевые слова: Иоанн Павел II, исключение, маргинализация, бедность, права человека 